PRINT ISSN 1119-8362

Electronic ISSN 1119-8362
Full-text Available Online at

https://www.ajol.info/index.php/jasem

http://ww.bioline.org.br/ja
J. Appl. Sci. Environ. Manage.

Vol. 25 (11) 1859-1868 November 2021

\title{
Concentration and Toxicological Risk Assessment of Heavy Metal Pollution in Dumpsite Soils within Benin City, Nigeria
}

\author{
${ }^{1}$ AGHO, TI; *1OKPARA, BC; ${ }^{2}$ AKUBUIRO, PC \\ ${ }^{*}$ Department of Animal and Environmental Biology, Faculty of Life Sciences, University of Benin, Benin City, Edo State, Nigeria \\ ${ }^{2}$ Department of Chemistry, Faculty of Physical Sciences, University of Benin, Benin City, Edo State, Nigeria \\ *Corresponding Author Email: benjamin.okpara@lifesci.uniben.edu
}

\begin{abstract}
Indiscriminate disposal of refuse and industrial effluents is a challenge in Nigeria. This poses a plethora of health and ecological risks from heavy metal contamination of soils. This study investigated the levels of heavy metal contamination in dumpsite soils and its effects on human health within Benin metropolis, Nigeria. The specific objectives were to determine the human and ecological risks via different exposure pathways. Soil samples were collected from three sampling stations, digested and analyzed for lead, cadmium, zinc, chromium, iron, nickel, manganese and copper using the Atomic Absorption Spectrophotometer (AAS). Pollution Indices and Human health risk were estimated using appropriate formulae. Results showed that that the mean concentrations of the investigated metals in the three stations were chromium $(17.12 \pm 1.00,17.65 \pm 1.05$ and, $17.24 \pm 1.05 \mathrm{mg} / \mathrm{kg})$, nickel $(37.60 \pm 7.95$, $40.98 \pm 1.46$ and, $41.25 \pm 0.92 \mathrm{mg} / \mathrm{kg}$ ), copper $(48.57 \pm 4.91,47.76 \pm 3.66$ and, $48.05 \pm 3.46 \mathrm{mg} / \mathrm{kg}$ ), lead $(8.2 \pm 0.22$, $8.17 \pm 0.52$ and, $8.25 \pm 0.16 \mathrm{mg} / \mathrm{kg}$ ), manganese $(94.52 \pm 4.90,94.98 \pm 6.69$ and, $95.06 \pm 4.63)$, iron $(467.98 \pm 36.69$, $464.90 \pm 22.36$ and, $462.15 \pm 10.64 \mathrm{mg} / \mathrm{kg})$, cadmium $(2.30 \pm 0.16,2.22 \pm 0.11$ and, $2.22 \pm 0.10 \mathrm{mg} / \mathrm{kg}$ ) and zinc $(142.93 \pm 3.93,142.29 \pm 3.41$ and $142.87 \pm 3.86 \mathrm{mg} / \mathrm{kg})$ respectively. Human health risk assessment revealed that the highest and lowest daily intake for the ingestion, inhalation and dermal pathway for both adults and children were Zinc and lead. Daily intake for children was higher than for adults via the three pathways with lifetime cancer risk (LCR) higher for children than adults. Carcinogenic and non-carcinogenic risk assessment shows that there were minimal risks from heavy metal contamination of the soils. Effective management and continuous monitoring of dumpsite soils is recommended to prevent negative impacts to man and the environment.
\end{abstract}

\section{DOI: https://dx.doi.org/10.4314/jasem.v25i11.3}

Copyright: Copyright $\left({ }_{0} 2021\right.$ Agho et al. This is an open access article distributed under the Creative Commons Attribution License (CCL), which permits unrestricted use, distribution, and reproduction in any medium, provided the original work is properly cited.

Dates: Received: 22 August 2021; Revised: 17 September 2021; Accepted: 06 October 2021

Keywords; Heavy metals; Dumpsite, Pollution Indices, risk assessment; hazard index, lifetime cancer risk (LCR).

Humanity has always interacted with nature since ancient times; however, the surge of industrialization, urbanization and a laissez faire attitude towards environmental sustainability, have negatively impacted various matrices of the ecosystem. Wastes are generated as a result of the activities of humans and the effective management of these wastes has become a daunting challenge especially in urban centers of developing countries due to inadequacy of waste management facilities and resources (Vongdala et al., 2019; Ajah et al., 2015). Soil is a vital component of the biosphere as it provides the medium to support growth of plants, assists in the natural process of nutrient recycling and maintenance of ecosystem services and life support systems. It also protects the global ecosystem from environmental pollutants by acting as a buffer, storage, filter and transformation system (Sumithra et al., 2013). Soil can be contaminated by disposing solid wastes directly into the soil, leachates or sludge deposition or following precipitation of toxic and harmful emissions from the air (Borah et al., 2017). The level of contamination of soils in waste dumps is a function of the type of waste, soil topography, surface run-off and the scavenging activities (Ideriah et al., 2007). Naturally, due to their filtering and buffering ability, soils are capable of biodegrading basically all organic wastes, turning them to innocuous substances. However, most inorganic products such as heavy metals, are not prone to biodegradation, thus persisting and accumulating to hazardous levels causing environmental pollution and spread of diseases (Olayiwola et al., 2017; Alloway and Ayres, 1997; Bakis and Tuncan, 2011). The chemical and physical properties of soils make it an excellent medium to study and monitor heavy metal pollution and environmental quality as it clearly reflects HM profiles originating from anthropogenic activities (Li et al., 2009; Borah et al., 2017). Most developing countries in the world including Nigeria, have not been able to effectively manage their wastes posing a significant hazard to the environment. This is a significant problem given the drive for the UN sustainable development goals 2030. For instance, In Nigeria, copious amounts of wastes are dumped 
uncensored in open dumpsites which pose a plethora of risk to inhabitants of nearby communities. The impacts of waste disposal on land include hampering of soil productivity, interference with soil flora and fauna, contamination of surface and ground water due to leachate movement and bioaccumulation of toxic heavy metals in the soil (Ajah et al., 2015). As contaminants move through the food chain and abound in the environment, humans can be exposed via dietary intake, inhalation or through the skin posing a significant health risk (Wang et al., 2019; Mungai et al., 2016). Risk assessments are vital in providing evidence-based data to make informed decisions aimed at reducing pollution, minimizing human exposure and protecting people from adverse effects if and when they occur (Chen et al., 2015, Crentsil and Anthony, 2016). Previous studies on dumpsites in Nigeria have focused on heavy metal concentrations without exploring the human and ecological risks.

Therefore, the present study examined the Concentration and Toxicological Risk Assessment of Heavy Metal Pollution in Dumpsite Soils within Benin City, Nigeria.

\section{MATERIALS AND METHODS}

Study area description: The study was done in a dumpsite in Ekenwan road in Benin City, Nigeria. The sampled dumpsite location as shown in Figure 1 lies between lat. $6^{\circ} 32^{\prime} \mathrm{N}, 6^{\circ} 33^{\prime} \mathrm{N}$ and Long. $5^{\circ} 58^{\prime} \mathrm{N}, 5^{\circ}$ $\left.59^{\prime} \mathrm{N}\right)$. The control site is a forest location which lies between Lat. $6^{\circ} 26^{\prime} \mathrm{N}$ and Long. $5^{\circ} 54^{\prime} \mathrm{N}$. The Climate is equatorial; with two distinct dry and wet seasons. The dry season is majorly from about November to March with cool harmattan dusty haze in December and January while the wet season spans from April to October. Annual rainfall amount in the Niger Delta region is about $2500 \mathrm{~mm}$ and $2673.8 \mathrm{~mm}$ while annual temperature is about $30^{\circ} \mathrm{C}$ and $32.8^{\circ} \mathrm{C}$ respectively. The vegetation is ever green forest or rainforest consisting of trees such as timber trees (Ebony, Iroko, and Mahogany), palm trees, fruit trees and shrubs. Mangrove swamps is along the coastal areas. The present status of both areas shows secondary vegetation because of rapid urbanization which has led to felling of trees and clearing of vegetation.

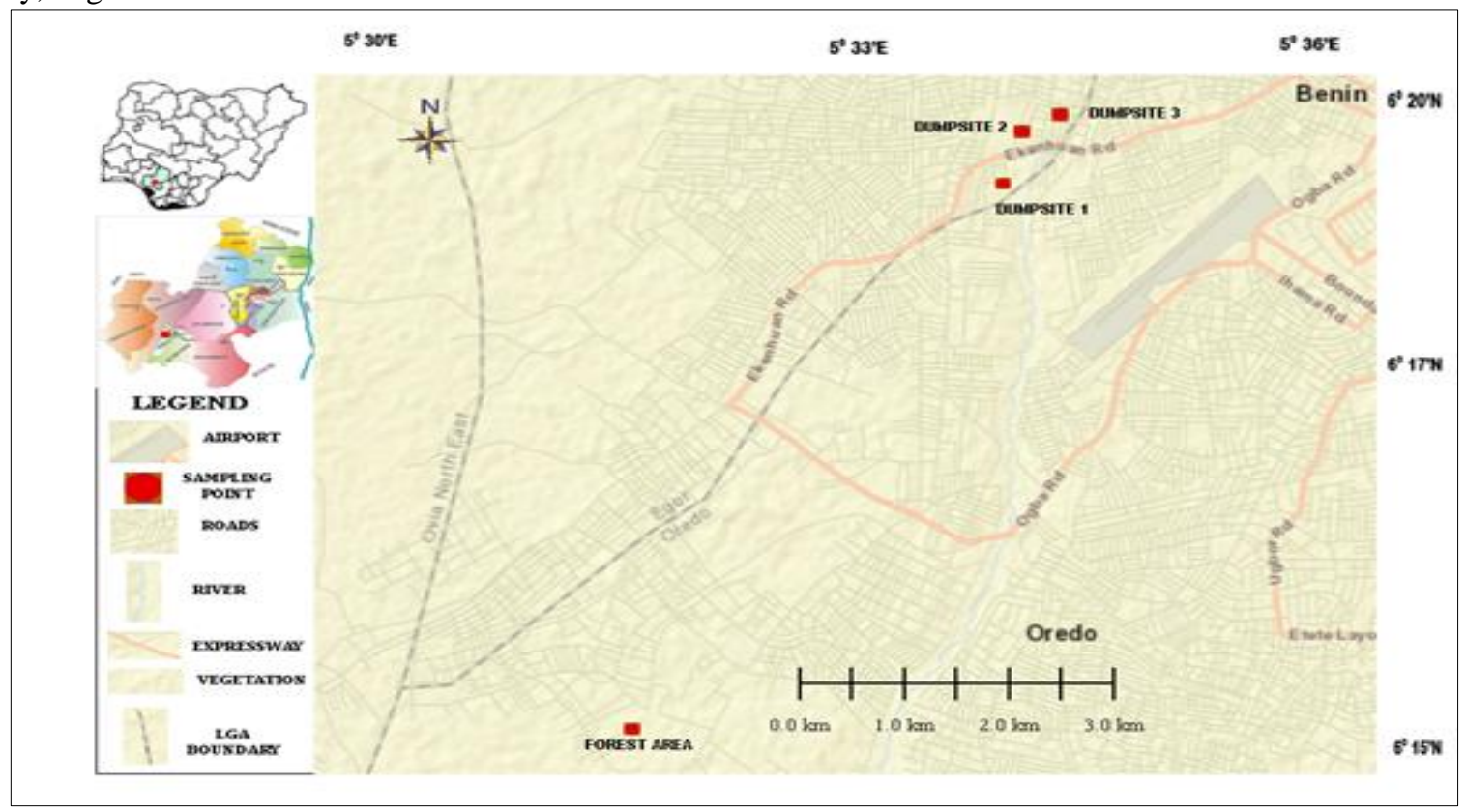

Fig 1: Map of the study area showing sampling points (Inset: Map of Nigeria and Edo state, Nigeria

Sampling strategy and analytical procedures: A total of thirty-six (36) samples were collected for three months, between September and November 2020 from soils in triplicates. Samples were collected at a depth of $20 \mathrm{~cm}$ using soil auger, they were then packed in a labelled polyethene and taken to the laboratory for preparation and analysis.

Sample preparations: The soil samples from the two locations were air-dried to constant weight at room temperature, crushed, and passed through a $2 \mathrm{~mm}$ mesh sieve prior to analysis. $1.0 \mathrm{~g}$ of each soil samples was weighed into a khedjahl flask $(100 \mathrm{ml})$ and $10 \mathrm{ml}$ of mixed acids (Nitric - perchloric ratio 2:1) was added. The solution was heated to fuming until a clear solution was achieved. The solution was allowed to cool, filtered and diluted with deionized water to 100 $\mathrm{ml}$ volumetric flask. A reagent blank solution was also prepared using same procedure. 
Estimating metal concentration in sample digests: Sample digests were analyzed for the concentrations of $\mathrm{Pb}^{2+}, \mathrm{Cd}^{2+}, \mathrm{Zn}^{2+}, \mathrm{Cr}^{3+}, \mathrm{Fe}^{2+}, \mathrm{Ni}^{2+}, \mathrm{Mn}^{2+}$ and $\mathrm{Cu}^{2+}$ using Atomic Absorption Spectrophotometer Buck Scientific (VGP 210) at the Ecotoxicology and Environmental Forensic Laboratory, University of Benin, Edo State Nigeria.

Pollution assessment of heavy metals:

Geoaccumulation Index (Igeo): The Igeo can be calculated using the following equation:

$\mathrm{I}_{\text {geo }}=\log _{2} \frac{C_{n}}{1.5 \times B_{n}}$

Where $C_{n}$ is the measured concentration of heavy metal in soil and $B_{n}$ is the geochemical background (average) in the earth's crust (Wedepohl, 1995). The constant factor 1.5 is used because of possible variations of the background data due to lithological variations.

The contamination levels were classified into seven classes by Muller (1969) as follows "Uncontaminated $($ Igeo $<0)=$ Class 0 ; Uncontaminated to moderately contaminated $(0<$ Igeo $\leq 1)=$ Class 1 , moderately contaminated $(1<$ Igeo $\leq 2)=$ Class 2 ; moderately to heavily contaminated $(2<$ Igeo $\leq 3)=$ Class 3 ; heavily contaminated $(3<$ Igeo $\leq 4)=$ class 4 ; heavily to extremely contaminated $(4<$ Igeo $\leq 5)=$ class 5 and extremely contaminated Igeo $>5=$ class 6"

Pollution load index: The Pollution Load Index (PLI) is the geometric mean of contamination factor $(\mathrm{CF})$ value of each metal at the contaminated site. It is evaluated by using the equation:

$\mathrm{PLI}=(\mathrm{CF} 1 \times \mathrm{CF} 2 \times \mathrm{CF} 3 \times \ldots \mathrm{CFn})^{1 / \mathrm{n}}$

Where $n=$ No. of metals $(n=8)$ in this study and CF $=$ contamination factor of each element present in the soil.

$\mathrm{CF}=\frac{C_{i}}{C_{b}}$

$\mathrm{PLI}=\sqrt[n]{C F_{1} \times C F_{2} \times \ldots C F_{n}}$

Contamination degree (CD): This estimates the total degree of overall contamination of a site. It is the sum of the contamination factors and it is expressed by the equation:

$\mathrm{CD}=\sum_{i=1}^{n} C F$
Contamination degree is classified by Hakanson (1980) as $\mathrm{CD}<6=$ low degree of contamination, $6 \leq$ $\mathrm{CD}<12=$ moderate degree of contamination, $12 \leq \mathrm{CD}$ $<24=$ considerable degree of contamination, and CD $\geq 24=$ very high degree of contamination.

Potential ecological risk index (RI): The Potential ecological risk index is used to estimate the ecological risk of heavy metals in soils by considering the toxicity of the metal and a comparison between the metal and the background value. The potential ecological risk can be estimated by the formula

$\Sigma_{r}^{i}=T_{r}^{i} \times \mathrm{CF}$

Where $\Sigma_{r}^{i}$ is the potential ecological risk, $T_{r}^{i}$ is the toxic factor and $\mathrm{CF}$ is the contamination factor (ratio of metal concentration to background values in shale). The toxic factors for the heavy metals $\mathrm{Ni}, \mathrm{Mn}, \mathrm{Cr}, \mathrm{Fe}$, $\mathrm{Zn}, \mathrm{Cu}$ and $\mathrm{Cd}$ are 5.0, 1.0, 2.0, 2.0, 1.0, 5.0 and 30.0 respectively (Hakanson, 1980; Jiao et al., 2015; Soliman et al., 2015).

The potential ecological risk for the dumpsite stations and the forest is the sum of the individual potential risks $\sum_{r}^{i}$ of the metals.

The classification is as follows: $\Sigma_{r}^{i} \leq 40=$ low ecological risk, $40<\Sigma_{r}^{i} \leq 80=$ moderate ecological risk, $80<\Sigma_{r}^{i} \leq 160=$ considerable ecological risk, 160 $<\Sigma_{r}^{i} \leq 320=$ high ecological risk, $\Sigma_{r}^{i}>320=$ very high ecological risk. The potential ecological risk is further classified as $\mathrm{RI} \leq 150=$ low ecological risk, $150<\mathrm{RI}$ $\leq 300=$ moderate ecological risk, $300<\mathrm{RI} \leq 600=$ considerable ecological risk, RI $>600=$ very high ecological risk.

Human health risk assessment of heavy metals Exposure Analysis: The average daily intake (ADI) was used to characterize the exposure to heavy metals via the inhalation, ingestion and dermal pathways. The ADI was calculated by the USEPA (1986, 2001) formulae the parameters are described in Table 1.

$$
\begin{aligned}
& \mathrm{ADI}_{\text {ingestion }}=\frac{C \times \mathrm{IngR} \times \mathrm{EF} \times \mathrm{ED}}{\mathrm{BW} \times \mathrm{AT}} \\
& \mathrm{ADI}_{\text {inhale }}=\frac{\mathrm{C} \times \mathrm{InhR} \times \mathrm{EF} \times \mathrm{ED}}{\mathrm{PEF} \times \mathrm{BW} \times \mathrm{AT}} \\
& \mathrm{ADI}_{\text {dermal }}=\frac{C \times C F \times S A \times A F \times A B S \times E F \times E D}{B W \times A T}
\end{aligned}
$$

Risk characterization: Risk assessment for toxic heavy metals is categorized into carcinogenic and noncarcinogenic risk assessment. Non-carcinogenic risk assessment is evaluated using a hazard quotient which is the ratio of $\mathrm{ADI}(\mathrm{mg} /(\mathrm{kg} /$ day $)$ to the specific 
reference dose (RfD, $\mathrm{mg} /(\mathrm{kg} / \mathrm{day})$ for a given metal. It is given by the equation

$$
\mathrm{HQ}=\frac{A D I}{R f D}
$$

The reference dose is the highest level at which a metal will have no harmful effect on human health (USEPA, 1991). The RfD for the metals for each exposure pathway are shown in Table 2.

The hazard Index (HI) is used to express the overall non-carcinogenic risk posed by a mixture of the metals. It is determined from the sum of the HQs for each heavy metal.

$\mathrm{HI}=\sum\left(\mathrm{HQ}_{\text {ingestion }}+\mathrm{HQ}_{\text {inhalation }}+\mathrm{HQ}_{\text {dermal }}\right)$
When $\mathrm{HI}<1$, it indicates an unlikely adverse effect from exposure while $\mathrm{HI}>1$ indicates that there could be a risk of non-carcinogenic effects.

Carcinogenic risk is an estimation of the likelihood of an individual developing cancer as a result of exposure to a carcinogen (Wang et al., 2017). For a given metal it is calculated as

$\mathrm{CR}=\sum_{i=0}^{n} C D I \times S F$

Total cancer risk (TCR) is the sum of the cancer risk for different metals given by

$\mathrm{TCR}=\sum_{i=0}^{n} C R$

$\mathrm{SF}=$ carcinogenic slope factor (permg/kg/day). Risks $<1.0 \times 10^{-6}$ are generally minimal and negligible while TCR > $1.0 \times 10^{-4}$ imply a lifetime carcinogenic risk. The SF for $\mathrm{Cr}$ and $\mathrm{Ni}$ are in Table 2.

Table 1: Parameters for Exposure assessment

\begin{tabular}{|c|c|c|c|c|}
\hline Factor & Description & Unit & Value & Reference \\
\hline $\mathrm{C}$ & Metal & $\mathrm{Mg} / \mathrm{kg}$ & & \\
\hline IngR & $\begin{array}{l}\text { Concentration } \\
\text { Ingestion rate }\end{array}$ & $\mathrm{mg} /$ day & $\begin{array}{l}100 \text { for adults, } \\
200 \text { for children }\end{array}$ & USEPA, 2001 \\
\hline $\operatorname{InhR}$ & $\begin{array}{l}\text { Inhalation } \\
\text { rate }\end{array}$ & & $\begin{array}{l}20 \text { for adults, } 10 \\
\text { for children }\end{array}$ & $\begin{array}{l}\text { Frimpong, S. K } \\
\text { and Koranteng, S. } \\
\text { S. (2019) }\end{array}$ \\
\hline $\mathrm{CF}$ & $\begin{array}{l}\text { Conversion } \\
\text { factor }\end{array}$ & $\mathrm{kg} / \mathrm{mg}$ & $10^{-6}$ & USEPA, 2001 \\
\hline $\mathrm{EF}$ & $\begin{array}{l}\text { Exposure } \\
\text { frequency }\end{array}$ & days/year & 365 & USEPA, 2001 \\
\hline ED & $\begin{array}{l}\text { Exposure } \\
\text { duration }\end{array}$ & Years & $\begin{array}{l}55.2 \text { for adults; } \\
6 \text { for children }\end{array}$ & $\begin{array}{l}\text { World Health } \\
\text { Rankings, } 2020\end{array}$ \\
\hline BW & Body weight & $\mathrm{Kg}$ & $\begin{array}{l}70 \text { for adults, } 15 \\
\text { for children }\end{array}$ & $\begin{array}{l}\text { Adimalla and } \\
\text { Wang, } 2018\end{array}$ \\
\hline AT & Average time & Day & $\begin{array}{l}20148 \text { for } \\
\text { adults; } 2190 \text { for } \\
\text { children }\end{array}$ & USEPA, 2001 \\
\hline PEF & $\begin{array}{l}\text { Particle } \\
\text { Emission } \\
\text { factor }\end{array}$ & $\mathrm{m}^{3} / \mathrm{kg}$ & $1.36 \times 10^{9}$ & USEPA, 2001 \\
\hline SA & Surface area & $\mathrm{cm}^{2}$ & $\begin{array}{l}3300 \text { for adults; } \\
2800 \quad \text { for } \\
\text { children }\end{array}$ & $\begin{array}{l}\text { Frimpong, S. K } \\
\text { and Koranteng, S. } \\
\text { S. (2019) }\end{array}$ \\
\hline $\mathrm{AF}$ & $\begin{array}{l}\text { Adherence } \\
\text { factor }\end{array}$ & & 0.2 & USEPA, 2011 \\
\hline ABS & $\begin{array}{l}\text { Dermal } \\
\text { absorption } \\
\text { factor }\end{array}$ & & 0.001 & USEPA, 2001 \\
\hline
\end{tabular}

Table 2: The reference RfD and SF of heavy metals (Wang et al., 2016 and Jafari et al., 2019)

\begin{tabular}{|c|c|c|c|c|}
\hline & $\begin{array}{l}\text { RfD }_{\text {ing }} \\
\text { (mgkg }^{-} \\
{ }^{1} \text { day }^{-1}\end{array}$ & $\begin{array}{l}\text { RfD }_{\text {inh }} \\
\text { (mgkg }^{-} \\
{ }^{1} \text { day }^{-1}\end{array}$ & $\begin{array}{l}\text { RfD }_{\text {der }} \\
\text { (mgkg }^{-} \\
{ }^{1} \text { day }^{-1}\end{array}$ & $\begin{array}{l}\text { SFinh } \\
\text { (kgdaymg }^{-1}\end{array}$ \\
\hline $\mathrm{Cr}$ & 0.003 & 0.0000286 & 0.00006 & 0.41 \\
\hline $\mathrm{Ni}$ & 0.02 & 0.0206 & 0.0054 & 0.84 \\
\hline $\mathrm{Cu}$ & 0.04 & 0.0402 & 0.012 & \\
\hline $\mathrm{Pb}$ & 0.0035 & 0.00352 & 0.000525 & \\
\hline $\mathrm{Zn}$ & 0.3 & 0.3 & 0.06 & \\
\hline
\end{tabular}


Statistical Analysis: Descriptive analysis (mean, range and standard deviation) was used to characterize heavy metal levels in the forest and the dumpsite. Test of significance between the dumpsite and the forest were determined using single factor ANOVA at 0.05 level of significance while post hoc test were done using Duncan multiple range test. All calculations were done using the statistical package for Social Sciences (SPSS) Version 23.0 and Microsoft Excel for Windows.

\section{RESULTS AND DISCUSSION}

Dumpsite management in many parts of Nigeria is a herculean task, leading to accumulation of heavy metals and other dangerous chemicals in the soil. The cultivation of crops in contaminated heavy metal laden soils, promotes the absorption, translocation and subsequent bioaccumulation of trace metals to toxic levels in edible plant tissues. Human exposure to toxic heavy metals can result from accumulation up the food chain. Thus, there is potential risk to human and animal health from consumption of harvested farm produce like vegetables, tubers, fruits and nuts grown on polluted soils around dumpsite areas.

Heavy metal Concentration in the Soils: The results obtained from the analysis of the data of heavy metals from the dumpsites and forest are shown in Table 3. The results revealed that iron had the highest concentration in the three investigated stations of dumpsites $\quad(467.98 \pm 36.69, \quad 464.90 \pm 22.36$, $462.15 \pm 10.64 \mathrm{mg} / \mathrm{kg}$ dry weight) and, in the forest $(244.96 \pm 228.14 \mathrm{mg} / \mathrm{kg}$ dry weight). However, the least concentration of metals was observed in cadmium, in both sampling sites (Station one $2.30 \pm 0.16$, Station two $2.22 \pm 0.11$ Station three $2.22 \pm 0.10 \mathrm{mg} / \mathrm{kg}$ dry weight; Forest $0.36 \pm 0.42$ $\mathrm{mg} / \mathrm{kg}$ dry weight). In general, the results showed that the relative abundance of heavy metals across the locations within the Dumpsites was in the order Fe > $\mathrm{Zn}>\mathrm{Mn}>\mathrm{Cu}>\mathrm{Ni}>\mathrm{Cr}>\mathrm{Pb}>\mathrm{Cd}$ and, in the forest used as control, the abundance of heavy metals was in the order $\mathrm{Fe}>\mathrm{Zn}>\mathrm{Mn}>\mathrm{Ni}>\mathrm{Cu}>\mathrm{Cr}$
$>\mathrm{Pb}>\mathrm{Cd}$ respectively. The results reported for $\mathrm{Zn}$, $\mathrm{Cu}, \mathrm{Pb}$ and, $\mathrm{Cd}$ as shown in Table 3 was highest in station one with the concentrations $142.93 \pm 3.93$, $48.57 \pm 4.91,8.29 \pm 0.22$ and $2.30 \pm 0.16 \mathrm{mg} / \mathrm{kg}$ respectively. $\mathrm{Mn}$ and $\mathrm{Ni}$ had the highest concentration in station three $(95.06 \pm 4.63,41.25 \pm 0.92 \mathrm{mg} / \mathrm{kg})$ while $\mathrm{Cr}$ highest concentration was observed in station two $17.65 \pm 0.01 \mathrm{mg} / \mathrm{kg}$. The concentration of iron obtained in this study was more pronounced in the dumpsites with station one having the highest concentration $(467.98 \pm 36.69 \mathrm{mg} / \mathrm{kg})$ as shown in Table 3 . The value in the control site $(244.96 \pm 22.14$ $\mathrm{mg} / \mathrm{kg}$ ) was comparatively lower although no significant difference $(\mathrm{P}>.05)$ was observed. Results of the one-way ANOVA showed that there was a significant difference $(p<0.05)$ in the concentration of $\mathrm{Ni}, \mathrm{Pb}, \mathrm{Cd}, \mathrm{Cu}, \mathrm{Zn}$ and $\mathrm{Cr}$ between the forest (control site) and the dumpsite stations. Only Mn and Fe showed no significant difference. This shows that the continuous dumping of waste in this area has led to heavy metal contamination of the soil. However, they were within International and National recommended permissible limit for metals in soil as shown in Table 3 (WHO, 1996; DPR, 2002). Furthermore, iron was highly concentrated in the soils compared to other metals. Although iron is abundantly present in most soils within the Benin metropolis, the higher accumulation of iron in the dumpsite soils can be attributed to the dumping of refuse laden with iron content in the dumpsite. This result is in agreement with those of Eddy et al., 2006; Essien et al., 2019 and Iyebor et al., 2020. Their studies showed a significant increase in the amount of iron in the dumpsites due to incessant dumping of waste materials with high iron content in the sites. However, pollution of the soil cannot be entirely attributed to waste materials alone as iron has been reported to occur in high proportion as the most abundant element in Nigerian soil (Ajibulu et al., 2013; Amusan, 2005). The correlation matrix of heavy metals in the dumpsite soil are shown in Table 4. Strong positive correlations were observed between $\mathrm{Pb} / \mathrm{Mn}$ (0.872), $\mathrm{Zn} / \mathrm{Cu}$ (0.986) and $\mathrm{Fe} / \mathrm{Cu}$ (0.993), $\mathrm{Fe} / \mathrm{Zn}$ (0.989), $\mathrm{Cr} / \mathrm{Cu}(0.750)$ and $\mathrm{Cr} / \mathrm{Fe}$ (0.778).

Table 3: Summary of heavy metal concentrations in the Dumpsite and Forest (control)

\begin{tabular}{|c|c|c|c|c|c|c|}
\hline \multirow{2}{*}{$\begin{array}{l}\text { HM } \\
(\mathrm{mg} / \mathrm{kg})\end{array}$} & \multirow{2}{*}{$\begin{array}{l}\text { Forest } \\
(\text { Mean } \pm \text { SD }\end{array}$} & \multirow[t]{2}{*}{ Range } & \multicolumn{3}{|c|}{ Dumpsite } & \multirow[t]{2}{*}{ Range } \\
\hline & & & Station 1 & Station 2 & Station 3 & \\
\hline $\mathrm{Ni}$ & $24.35 \pm 9.21^{\mathrm{a}}$ & $12.16-32.15$ & $37.60 \pm 7.95^{b}$ & $40.98 \pm 1.46^{b}$ & $41.25 \pm 0.92^{b}$ & $28.42-42.67$ \\
\hline $\mathrm{Mn}$ & $74.74 \pm 59.07$ & $28.17-141.18$ & $94.52 \pm 4.90$ & $94.98 \pm 6.69$ & $95.06 \pm 4.63$ & $89.62-104.32$ \\
\hline $\mathrm{Pb}$ & $4.04 \pm 1.75^{\mathrm{a}}$ & $2.07-5.41$ & $8.29 \pm 0.22$ & $8.17 \pm 0.52^{b}$ & $8.25 \pm 0.16^{\mathrm{b}}$ & $8.14-8.54$ \\
\hline $\mathrm{Cd}$ & $0.36 \pm 0.42^{\mathrm{a}}$ & $0.12-0.84$ & $2.30 \pm 0.16^{\mathrm{b}}$ & $2.22 \pm 0.11^{\mathrm{b}}$ & $2.22 \pm 0.10^{\mathrm{b}}$ & $2.12-2.62$ \\
\hline $\mathrm{Cu}$ & $20.19 \pm 3.48^{\mathrm{a}}$ & $18.12-51.50$ & $48.57 \pm 4.91^{b}$ & $47.76 \pm 3.66^{b}$ & $48.05 \pm 3.46^{\mathrm{b}}$ & $40.45-51.50$ \\
\hline $\mathrm{Zn}$ & $119.28 \pm 42.56^{\mathrm{a}}$ & $42.11-56.28$ & $142.93 \pm 3.93^{b}$ & $142.29 \pm 3.41^{b}$ & $142.87 \pm 3.86^{\mathrm{b}}$ & $138.35-145.20$ \\
\hline $\mathrm{Fe}$ & $244.96 \pm 228.14$ & $38.12-489.65$ & $467.98 \pm 36.69$ & $464.90 \pm 22.36$ & $462.15 \pm 10.64$ & $420.17-425.62$ \\
\hline $\mathrm{Cr}$ & $5.53 \pm 1.28^{a}$ & $4.19-6.73$ & $17.12 \pm 1.00^{\mathrm{b}}$ & $17.65 \pm 0.01^{b}$ & $17.24 \pm 1.05^{b}$ & $15.11-18.30$ \\
\hline
\end{tabular}


Metal Pollution at different sites: The Igeo results showed that all the investigated sites were uncontaminated (i.e., class 0 ) except for $\mathrm{Cu}, \mathrm{Zn}$ and Cr. While the forest (control) site had an uncontaminated to moderately contaminate class 1 index for $\mathrm{Cu}$, the dumpsites were moderately contaminated and situated within class 2 ranking. For $\mathrm{Cr}$, the control site was uncontaminated, unlike the dumpsites which ranged from uncontaminated to moderately contaminated (class 1 ) sites. However, all sites were moderately contaminated with $\mathrm{Zn}$ (class 2 ). Pollution severity and its variation along the sites were determined with the use of pollution load index. PLI is a quick tool which gives insight on the number of pollutants discharged into a body; it is widely used to compare the pollution status of different places (Adebowale et al., 2009). The results of the contamination degree and Pollution Load index (PLI) is shown in Table 5. The contamination degree of
$6.709,6.685$ and, 6.702 in stations one, two and three of the dumpsites; and a pollution load index of 0.315 , 0.317 and, 0.317 for the respective investigated dumpsites as shown in table 3 . The results showed that soils within the investigated dumpsites were moderately contaminated with low risk of potentially toxic metals as at the period this study was carried-out. This suggests that the waste impacted soil was not contaminated to an alarming degree as described by Thomilson, 1980. The concentration of the heavy metals and ecological sensitivity of heavy metals were comprehensively evaluated. The results obtained revealed a potential risk index of 21.24 in the forest, 100.60 in station one, 97.97 in station two and, 97.79 in station three of the dumpsites respectively. The potential ecological risk of the soils in this study showed that there was a considerable ecological risk in the dumpsite while that in the forest was low.

Table 4: Correlation Matrix of heavy metals in dumpsite soils

\begin{tabular}{|c|c|c|c|c|c|c|c|c|}
\hline & Nickel & Manganese & Lead & Cadmium & Copper & Zinc & Iron & Chromium \\
\hline Nickel & 1.000 & & & & & & & \\
\hline Manganese & -.530 & 1.000 & & & & & & \\
\hline Lead & $-.791 *$ & $.872 * *$ & 1.000 & & & & & \\
\hline Cadmium & $-.698 *$ & $.959 * *$ & $.926 * *$ & 1.000 & & & & \\
\hline Copper & .371 & $-.980^{* * *}$ & $-.778 *$ & $-.916^{* *}$ & 1.000 & & & \\
\hline Zinc & .497 & $-.996 * *$ & $-.834 * *$ & $-.949 * *$ & $.986 * *$ & 1.000 & & \\
\hline Iron & .444 & $-.990 * *$ & $-.821 * *$ & $-.941 * *$ & $.993 * *$ & $.989 * *$ & 1.000 & \\
\hline Chromium & $.728 *$ & $-.851 * *$ & $-.958 * *$ & $-.850 * *$ & $.750 *$ & $.818^{* *}$ & $.778 *$ & 1.000 \\
\hline
\end{tabular}

Table 5: Contamination assessment of heavy metals in the forest and dumpsite soils

\begin{tabular}{lllllllll}
\hline \multirow{2}{*}{ Metals } & \multicolumn{3}{c}{ CF, CD, PLI and PERI of metals } & \multicolumn{3}{c}{ Igeo } \\
\cline { 2 - 9 } & Forest & \multicolumn{3}{c}{ Dumpsite } & Forest & \multicolumn{3}{c}{ Dumpsite } \\
\hline & & STN 1 & STN 2 & STN 3 & & STN 1 & STN 2 & STN 3 \\
\hline $\mathrm{Ni}$ & 0.696 & 1.074 & 1.171 & 1.179 & -2.067 & -1.44 & -1.316 & -1.306 \\
$\mathrm{Mn}$ & 0.088 & 0.111 & 0.112 & 0.112 & -4.092 & -3.754 & -3.747 & -3.746 \\
$\mathrm{~Pb}$ & 0.048 & 0.098 & 0.096 & 0.097 & -1.366 & -0.329 & -0.35 & -0.336 \\
$\mathrm{Cd}$ & 0.450 & 2.875 & 2.775 & 2.775 & -5.597 & -2.922 & -2.973 & -2.973 \\
$\mathrm{Cu}$ & 0.561 & 1.349 & 1.327 & 1.335 & 0.212 & 1.478 & 1.454 & 1.463 \\
$\mathrm{Zn}$ & 0.852 & 1.018 & 1.016 & 1.021 & 1.657 & 1.918 & 1.912 & 1.918 \\
$\mathrm{Fe}$ & 0.006 & 0.012 & 0.012 & 0.012 & -1.156 & -0.222 & -0.232 & -0.241 \\
$\mathrm{Cr}$ & 0.055 & 0.171 & 0.177 & 0.172 & -0.551 & 1.078 & 1.124 & 1.09 \\
$\mathrm{CD}$ & 2.756 & 6.709 & 6.685 & 6.702 & & & & \\
$\mathrm{PLI}$ & 0.147 & 0.315 & 0.317 & 0.317 & & & & \\
$\mathrm{PERI}$ & 21.24 & 100.60 & 97.97 & 97.97 & & & & \\
\hline
\end{tabular}

Human Health Risk Assessment: Some lifethreatening diseases which afflict humanity are attributed to gradual heavy metal accumulation via various channels of contamination such as soil, water and, air; which ultimately affects the food chain. To properly evaluate the human health risk as a result of accumulation of heavy metals in the soils, exposure analysis via inhalation, ingestion and dermal pathways were calculated for adults and children. Thereafter, the human health-risk assessment of the soil toxicants was determined on the basis of non-carcinogenic and carcinogenic effects. The exposure analysis via the three pathways is shown in figure $2-4$. Results showed that the highest and lowest daily intake for the ingestion, inhalation and dermal pathway for both adults and children were for Zinc and lead. This was consistent in all the routes of exposure. Based on all the pathways, the ingestion route was higher than the inhalation and dermal routes of exposure for all the elements. The general pattern observed was ingestion $>$ dermal > inhalation. The daily intake for children were generally higher than for adults via the three pathways. This is consistent with previous findings reported in northeast China (Quan et al., 2015) and northern Telangana, India (Adimalla and Wang, 2018). Children are at a higher propensity due to their 
playful habits and at a higher risk of metal contamination than adults. Heavy metals have also been known to induce carcinogenesis. They do this by increasing the generation of reactive oxygen species (ROS), causing DNA (Deoxyribonucleic acid) damage and by interfering with the expression of tumor suppression genes (To et al., 2015). The noncarcinogenic effects of the heavy metals were evaluated using the hazard quotient and hazard index. The Hazard index is a summation of the HQ from the three routes of exposure. Hazard Index less than 1 indicates no carcinogenic risk while above 1 indicates a non-carcinogenic risk. The results shown in Table 7 shows that chromium had the highest total hazard quotient for adults (1.11E-02) and children (8.57E02).

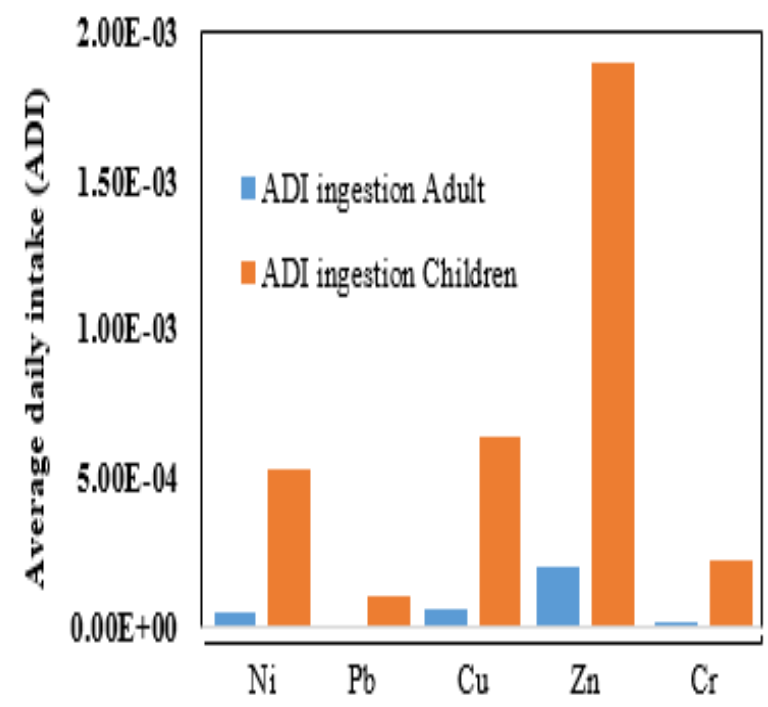

Fig 2: Average daily intake via the ingestion pathway

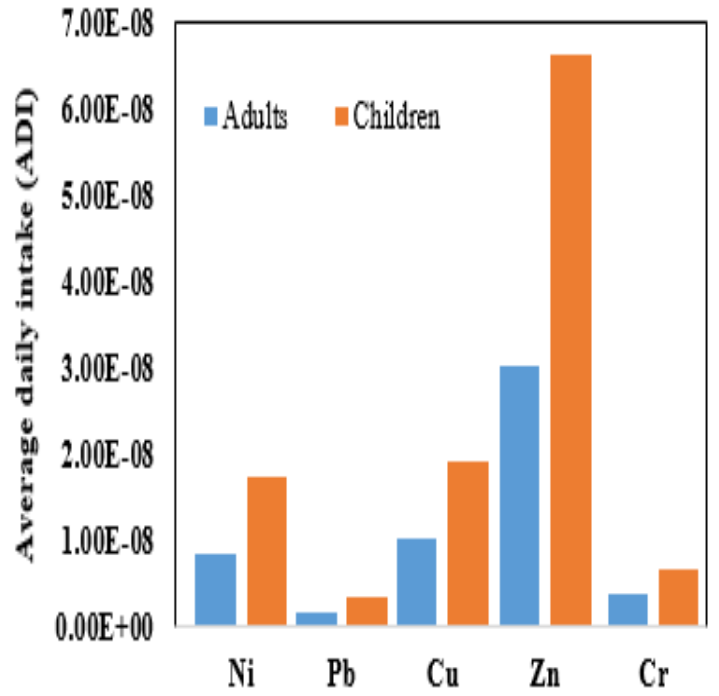

Fig 2: Average daily intake via the ingestion pathway

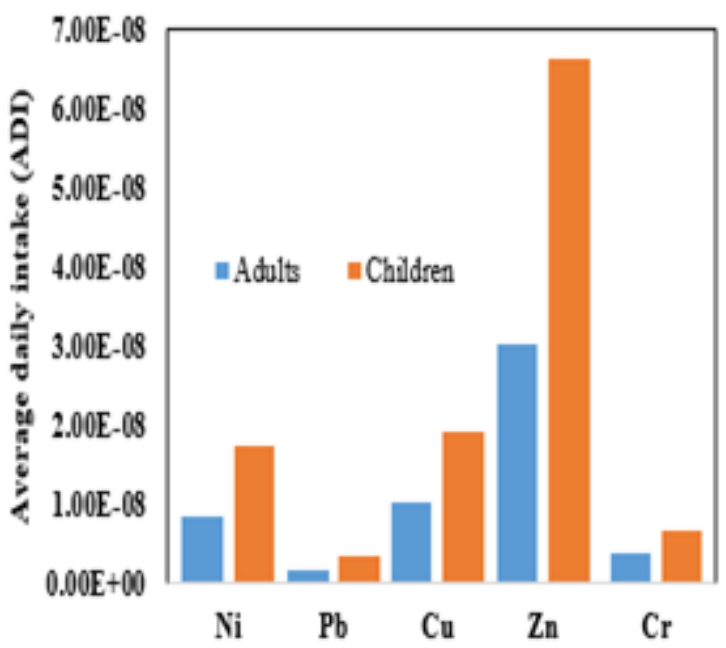

Fig 3: Average daily intake via the inhalation pathway

Table 7: Non-Carcinogenic Risk Assessment of Heavy metals in dumpsite area via ingestion, inhalation and dermal pathways for adults and children

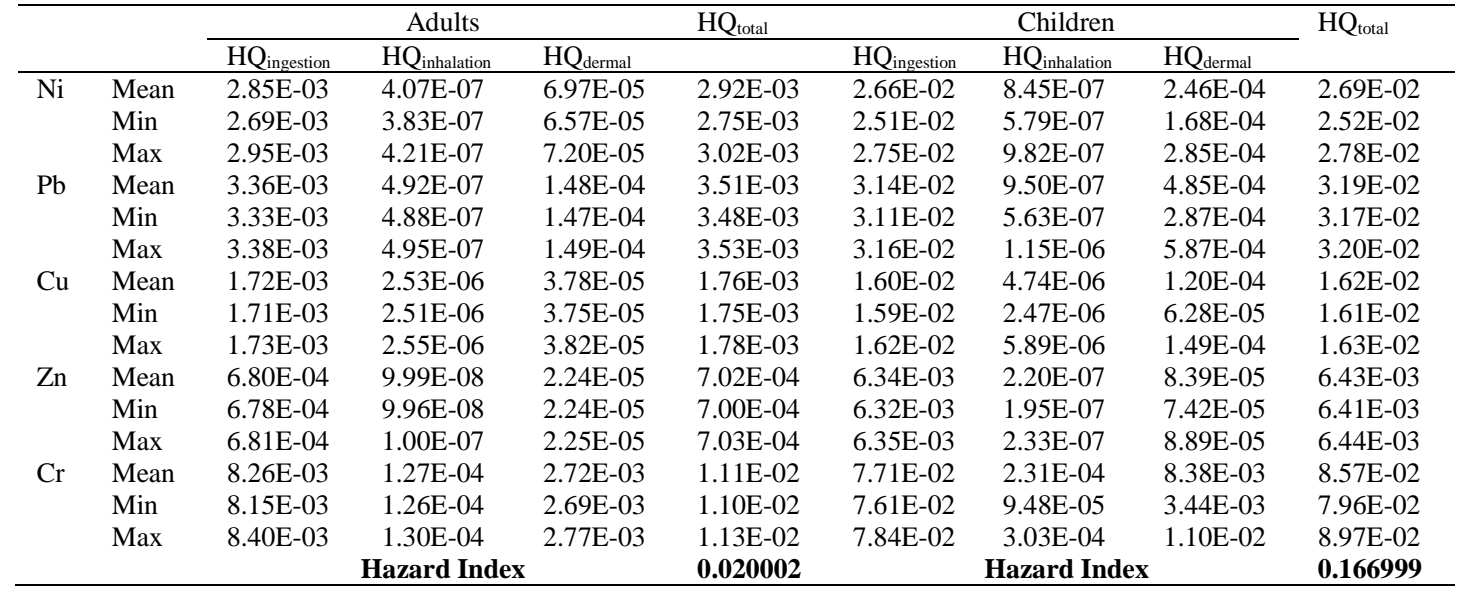


Table 8: Carcinogenic Risk Assessment for adults and children

\begin{tabular}{|c|c|c|c|c|c|c|c|c|c|}
\hline & & \multicolumn{3}{|c|}{ Adults } & \multirow[t]{2}{*}{ LCR } & \multicolumn{3}{|c|}{ Children } & \multirow[t]{2}{*}{ LCR } \\
\hline & & $\mathbf{C R}_{\text {ingestion }}$ & $\mathbf{C R}_{\text {inhalation }}$ & $\mathbf{C R}_{\text {dermal }}$ & & $\mathbf{C R}_{\text {ingestion }}$ & $\mathbf{C R}_{\text {inhalation }}$ & $\mathbf{C R}_{\text {dermal }}$ & \\
\hline \multirow[t]{3}{*}{$\mathrm{Ni}$} & Mean & $4.79 \mathrm{E}-05$ & $7.05 \mathrm{E}-09$ & $3.16 \mathrm{E}-07$ & $4.83 \mathrm{E}-05$ & $4.47 \mathrm{E}-04$ & $1.46 \mathrm{E}-08$ & $1.11 \mathrm{E}-06$ & $4.48 \mathrm{E}-04$ \\
\hline & Min & $4.51 \mathrm{E}-05$ & 6.64E-09 & 2.98E-07 & 4.54E-05 & 4.21E-04 & $1.00 \mathrm{E}-08$ & 7.64E-07 & $4.22 \mathrm{E}-04$ \\
\hline & $\operatorname{Max}$ & 4.95E-05 & $7.28 \mathrm{E}-09$ & $3.27 \mathrm{E}-07$ & $4.98 \mathrm{E}-05$ & $4.62 \mathrm{E}-04$ & $1.70 \mathrm{E}-08$ & $1.29 \mathrm{E}-06$ & $4.63 \mathrm{E}-04$ \\
\hline \multirow[t]{3}{*}{$\mathrm{Pb}$} & Mean & $5.88 \mathrm{E}-03$ & $8.65 \mathrm{E}-07$ & $3.88 \mathrm{E}-05$ & $5.92 \mathrm{E}-03$ & 5.49E-02 & $1.67 \mathrm{E}-06$ & $1.27 \mathrm{E}-04$ & $5.50 \mathrm{E}-02$ \\
\hline & Min & $5.84 \mathrm{E}-03$ & 8.58E-07 & $3.85 \mathrm{E}-05$ & $5.88 \mathrm{E}-03$ & $5.45 \mathrm{E}-02$ & $9.90 \mathrm{E}-07$ & $7.54 \mathrm{E}-05$ & $5.46 \mathrm{E}-02$ \\
\hline & Max & $5.92 \mathrm{E}-03$ & $8.71 \mathrm{E}-07$ & $3.91 \mathrm{E}-05$ & $5.96 \mathrm{E}-03$ & $5.53 \mathrm{E}-02$ & 2.02E-06 & $1.54 \mathrm{E}-04$ & $5.53 \mathrm{E}-02$ \\
\hline \multirow[t]{3}{*}{$\mathrm{Cd}$} & Mean & $1.96 \mathrm{E}-03$ & $2.88 \mathrm{E}-07$ & $1.29 \mathrm{E}-05$ & $1.97 \mathrm{E}-03$ & $1.83 \mathrm{E}-02$ & 4.78E-07 & $3.64 \mathrm{E}-05$ & $1.83 \mathrm{E}-02$ \\
\hline & Min & $1.93 \mathrm{E}-03$ & 2.84E-07 & $1.28 \mathrm{E}-05$ & $1.95 \mathrm{E}-03$ & $1.81 \mathrm{E}-02$ & $1.08 \mathrm{E}-07$ & $8.20 \mathrm{E}-06$ & $1.81 \mathrm{E}-02$ \\
\hline & $\operatorname{Max}$ & $2.00 \mathrm{E}-03$ & 2.95E-07 & $1.32 \mathrm{E}-05$ & $2.02 \mathrm{E}-03$ & $1.87 \mathrm{E}-02$ & $6.64 \mathrm{E}-07$ & $5.06 \mathrm{E}-05$ & $1.87 \mathrm{E}-02$ \\
\hline \multirow{3}{*}{$\mathrm{Cr}$} & Mean & $1.02 \mathrm{E}-03$ & 1.49E-07 & $6.70 \mathrm{E}-06$ & $1.02 \mathrm{E}-03$ & $9.48 \mathrm{E}-03$ & $2.71 \mathrm{E}-07$ & $2.06 \mathrm{E}-05$ & $9.50 \mathrm{E}-03$ \\
\hline & Min & $1.00 \mathrm{E}-03$ & $1.47 \mathrm{E}-07$ & $6.62 \mathrm{E}-06$ & $1.01 \mathrm{E}-03$ & $9.36 \mathrm{E}-03$ & $1.11 \mathrm{E}-07$ & $8.46 \mathrm{E}-06$ & $9.37 \mathrm{E}-03$ \\
\hline & $\operatorname{Max}$ & $1.03 \mathrm{E}-03$ & $1.52 \mathrm{E}-07$ & $6.82 \mathrm{E}-06$ & $1.04 \mathrm{E}-03$ & $9.65 \mathrm{E}-03$ & $3.55 \mathrm{E}-07$ & $2.70 \mathrm{E}-05$ & $9.68 \mathrm{E}-03$ \\
\hline
\end{tabular}

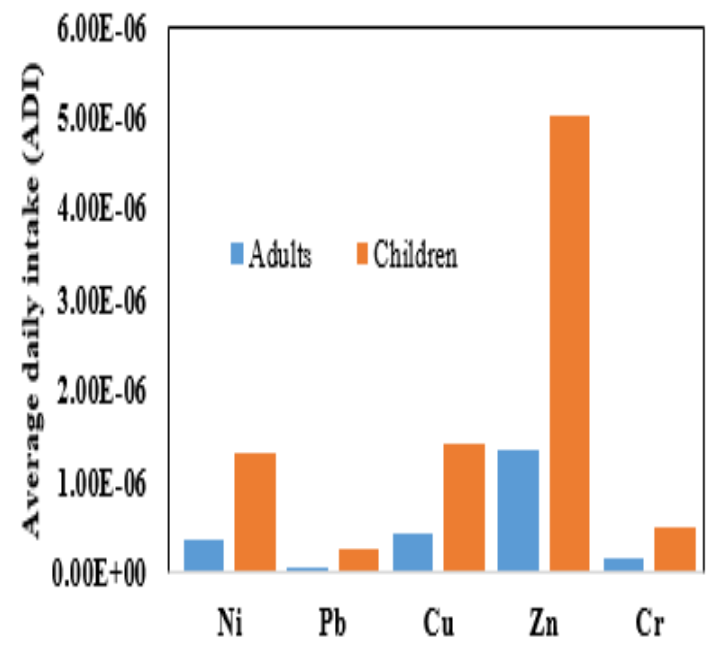

Fig 4: Average daily intake via the dermal pathway

The hazard index for adults and children were 0.020002 and 0.166999 respectively and were both less than 1 indicating no non-carcinogenic health risk to inhabitants of the community. Previous reports have shown that nickel, lead, cadmium and chromium have both carcinogenic and non-carcinogenic effects (Kamunda et al., 2016). Hence carcinogenic risk was also evaluated for these metals. Results shown in Table 8 shows that the lifetime cancer risk (LCR) of the investigated metals was higher for children than for adults.

Conclusion: The results obtained from the investigated dumpsites shows that the level of metals in the dumpsites were within permissible limits, however the continuous accumulation of metals in the soils, if not checked over a period of time, would render the site unsuitable for use, either for industrial or domestic use. More so, based on health quotient, the health risks posed to children and adults suggest that children are at higher risk. Nevertheless, the threshold limits of daily intake for the various pathways were not exceeded, thus acceptable. For future use, it is recommended that remediation must be carried out on the soils.

\section{REFERENCES}

Adebowale, K; Agunbide, F; Olu-Owolabi, B (2009). "Trace metal concentration, site variations and partitioning pattern in water and bottom sediments from coastal area: A case study of Ondo Coast, Nigeria". Environ. Res. J. 3(2): 4659.

Adimalla, N; Wang, H (2018). Distribution, contamination, and health risk assessment of heavy metals in surface soils from northern Telangana, India. Arab. J. Geosci. 11(684): 1-15.

Ajah, K; Ademiluyi, J; Nnaji, C (2015). Spatiality, seasonality and ecological risks of heavy metals in the vicinity of a degenerate municipal central dumpsite in Enugu. Nigeria J. Environ. Health Sci. \& Eng. 13(15): 1-14.

Ajibulu, K; Adefemi, O; Asaolu, S; Oyakhilome G (2013). Determination of heavy metals in soil samples of selected sawmills in Ekiti State, Nigeria. J. Sci. Res. and Report. 2(2): 513-521.

Alloway, B; Ayres, D (1997). Chemical Principles of Environmental Pollution, Second Edition, Blackie Academic and Professional, Chapman and Hall, London. J. Environ. Earth Sci. 7(4): 190-242.

Amusan, A; Ige, D; Olawale, R (2005). Characteristics of soils and crops' uptake of metals in municipal waste dump site in Nigeria. J. Human Eco. 17(3): 167-171.

Bakis, R; Tuncan, A (2011). An investigation of heavy metal and migration through groundwater from the landfill area of Eskisehir in Turkey. Environ. Monit. Assess. 176: 87-98. 
Borah, P; Paul, A; Bora, P; Bhattacharyya, P; Karak, T; Mitra, S (2017). Assessment of heavy metal pollution in soils around a paper mill using metal fractionation and multivariate analysis. Int. J. environ. Sci. Technol. 14(12):1-14.

Chen, HY; Teng, YG; Lu, SJ (2015). Contamination features and health risk of soil heavy metals in China. Sci. Total. Environ. 512-513: 143-53.

Crentsil, K; Anthony, E (2016). Heavy metal contamination and human health risk assessment around Obuasi Gold mine in Ghana. Environ. Monit. Assess. 188: 1-13.

DPR (Department of petroleum resources). 2002, Environmental guidelines and standards for the petroleum industry in Nigeria (revised ed.). Nigeria: Ministry of Petrol. and Nat. Res. Dept of Petrol. Res.

Eddy, N; Odoemelem, S; Mbaba, A (2006). Elemental composition of soil in some dumpsites. Elect. J. Environ. Agric. and Food Chem. 5(3): 1349-1365.

Essien, J; Inam, E; Ikpe, D; Udofia, G; Benson, N (2019). Ecotoxicological status and risk assessment of heavy metals in municipal solid wastes dumpsite impacted soil in Nigeria. Environ. Nanotechn. Monit. \& Manage. 11:100215.

Frimpong, S; Koranteng, S (2019). Levels and human health risk assessment of heavy metals in surface soil of public parks in Southern Ghana. Environ. Monit. Assess. 191(9): 588.

Håkanson, L (1980). An ecological risk index for aquatic pollution control. A sedimentological approach, Water Res. 14: 975-1001.

Ideriah, T; Omuaru, V; Osaisai, C (2007). Current Topics in Toxicology. 4: 45-50.

Iyebor, E; Olomukoro, J; Nwankwe, D (2020). Assessment of Heavy Metals Concentrations in Dumpsites Soils in Benin City, Edo State, Nigeria. Inter. J. Sci. Tech. Res. Eng. 5(2): 28-39.

Jafari, A; Ghaderpoori, M; Kamarehi, B; Abdipour, H (2019). Soil pollution evaluation and health risk assessment of heavy metals around Douroud cement factory, Iran. Environ. Earth Sci. 78:250.

Jiao, X; Teng, Y; Zhan, Y; Wu, J; Lin, X (2015). Soil heavy metal pollution and risk assessment in
Shenyang industrial district, Northeast China. PLoS One. 10(5): e0127736.

Kamunda C; Mathuthu M; Madhuku M (2016). Health risk assessment of heavy metals in soils from Witwatersrand gold mining basin, South Africa. Int. J. Environ. Res. Public Health. 13: 663-674.

Li, F; Fan, P; Xiao, P; Oh, K; Ma, X; Hou, WP (2009). Contamination, chemical speciation and vertical distribution of heavy metals in soils of an old and large industrial zone in Northeast China. Environ. Geo. 57: 1815-1823.

Müller, G (1969). Index of geoaccumulation in sediments of the Rhine River. Geo. J. 2: 108-118

Mungai, T; Owino, A; Makokha, V; Gao, Y; Yan, X; Wang, J (2016). Occurrences and Toxicological risk assessment of eight heavy metals in agricultural soils from Kenya, Eastern Africa. Environ. Sci. Pollut. Res. 23: 18533-18541.

Olayiwola, H; Abudulawal, L; Adewuyi, G; Azeez, M (2017). Heavy Metal Contents in Soil and Plants at Dumpsites: A Case Study of Awotan and Ajakanga Dumpsite Ibadan, Oyo State, Nigeria. J. Environ. Earth. Sci. 7(4): 11-24.

Quan, S; Yan, B; Yang, F; Li, N; Xiao, X; Fu, J (2015). Spatial distribution of heavy metal contamination in soils near a primitive ewaste recycling site. Environ. Sci. Pollut. Res. 22(2): 1290-1298.

Soliman, N; Nasr, S; Okbah, M (2015). J Environ Health Sci. Eng. 13:70 doi10.1186/s40201-0150223-X

Sumithra, S; Ankalaiah, C; Janardhana, R; Amuna, R (2013). A case study on physicochemical characteristics of soil around industrial and agricultural area of Yerraguntla, Kadapa district, A.P, India. Inter. J. Geo. Earth. Environ. Sci. 3(2): 28-34.

Thomilson, DC; Wilson, DJ; Harris, CR (1980). Problem in heavy metals in estuaries and the formation of pollution index. Helgol. Mar. Res. 33: $566-575$.

To, T; Feldman L; Simatovic J; Gershon AS; Dell S; Su J; Foty R; Licskai, C (2015). Health risk of air pollution on people living with major chronic diseases: a Canadian population-based study. BMJ Open. 2015; 5(9):e009075. 
US EPA (1986). Risk Assessment Guidance for Superfund Volume I Human Health Evaluation Manual (Part A), US EPA. https://doi. org/EPA/540/1-89/002

USEPA (2001). Supplemental guidance for developing soil screening levels for superfund sites. OSWER, Washington, DC.

USEPA (2011). Exposure factors handbook 2011 edition (Final). Office of Emergency and Remedial Response, Washington.

Vongdala, N; Tran, H; Xuan, TD; Teschke, R; Khanh, TD (2019). Heavy Metal Accumulation in Water, Soil, and Plants of Municipal Solid Waste Landfill in Vientiane, Laos. Int. J. Environ. Res. Public Health. 16(22): 1- 13
Wang, S; Wu, W; Lui, F (2019). Assessment of the human health risks of heavy metals in nine typical areas. Environ. Sci. Pollut. Res. 26: 12311-12323.

Wedepohl, KH (1995). The composition of the continental crust. Geochimicaet. Cosmochimicia. Acta. 59: 1217 - 1232.

WHO (1996). Permissible Limits of Heavy Metals in Soil and Plants. Geneva, World Health Organization, Switzerland. http://whqlibdoc.who.int/trs/WHO_TRS_505.pdf

World Health Rankings 2020 Nigeria Life Expectancy available https://www.worldlifeexpectancy,com/nigerialife-expectancy accessed 25th August 2020 